\title{
Evolving Diagnostic and Treatment Strategies for Pancreatic Neuroendocrine Tumors
}

\author{
Matthew H Kulke ${ }^{1 *}$, Johanna Bendell ${ }^{2}$, Larry Kvols ${ }^{3}$, Joel Picus ${ }^{4}$, Rodney Pommier ${ }^{5}$ and James Yao ${ }^{6}$
}

\begin{abstract}
Pancreatic neuroendocrine tumors (NET) have diverse clinical presentations. Patients with symptoms of hormone secretion may require specific medical interventions to control those symptoms prior to antitumor intervention. In some patients, tumors in the pancreas may be occult and specialized diagnostic imaging or surgery may be required for diagnosis. Other patients may present with more advanced disease, presenting with symptoms of tumor bulk rather than hormone secretion. Treatment options for patients with advanced pancreatic neuroendocrine tumors include surgical resection and hepatic directed therapies, including partial hepatectomy, hepatic artery embolization, or other ablative techniques. Streptozocin or temozolomide-based chemotherapy regimens are active against pancreatic NET, and can also play an important role in the palliation of patients with advanced disease. A number of biologically targeted agents targeting the VEGF and mTOR signaling pathways have recently shown promise, with recent trials showing treatment with the VEGFR tyrosine kinase inhibitor sunitinib or the mTOR inhibitor everolimus improves progression-free survival in patients with advanced NET.
\end{abstract}

\section{Introduction}

Pancreatic neuroendocrine tumors (NET) have been considered rare, with an estimated incidence of less than 1 per 100,000 individuals [1]. In recent years, however, the diagnosed incidence of pancreatic NET has increased, an observation that is likely due, at least in part, to improved detection and classification [2]. The diverse and sometimes non-specific clinical syndromes associated with pancreatic NET can make these malignancies difficult to diagnose at an early stage. Awareness of the clinical presentation and treatment options for patients with pancreatic NET has become increasingly relevant for both medical oncologists and other health care providers, as new treatment options emerge for patients with this disease.

\section{Histologic Classification and Staging}

Pancreatic NET have also been referred to as pancreatic islet cell tumors or pancreatic endocrine tumors. Carcinoid tumors have a similar histologic appearance to pancreatic NET, but generally arise in the bronchi, small intestine, appendix, or rectum. While the term "pancreatic carcinoid" has also sometimes been used to describe

\footnotetext{
* Correspondence: matthew_kulke@dfci.harvard.edu

${ }^{1}$ Dana-Farber Cancer Institute, Boston MA, USA

Full list of author information is available at the end of the article
}

pancreatic NET, this term is considered confusing as the clinical presentation and treatment options for pancreatic NET differ in many respects from those for carcinoid tumors.

The majority of pancreatic NET occur sporadically. However, pancreatic NET can be associated with inherited genetic syndromes; in particular, approximately $10 \%$ may be associated with multiple endocrine neoplasia type 1 (MEN1). MEN1 is an autosomal dominant syndrome associated with mutations in the tumor suppressor gene menin, and is characterized by the development of multiple NET involving not only the pancreas but also the parathyroid and pituitary glands [3]. Pancreatic NET have also been associated with MEN2, Von Hippel-Lindau disease, tuberous sclerosis, and neurofibromatosis.

The histologic features of pancreatic NET can vary, affecting both prognosis and treatment recommendations. An important first step following the diagnosis of a pancreatic malignancy is the differentiation of neuroendocrine cancers from the far more common pancreatic adenocarcinoma. Though the pathologic criteria for differentiating these two entities are clear, limited tissue from fine needle aspirations or endoscopic brushings may preclude accurate diagnosis. In questionable cases, repeat tissue sampling should be performed, particularly if systemic treatments are being considered.

\section{Biomed Central}


Adequate tissue sampling is also critical in differentiating the various subtypes of pancreatic NET. These tumors may fall within a broad spectrum of well-differentiated, low grade tumors to more poorly differentiated, high grade tumors. While a number of histologic classification systems have been proposed for pancreatic NET, tumors with a mitotic count $>20 / 10$ high powered fields or a Ki-67 proliferation index of $>20 \%$ generally represent highly aggressive malignancies where treatment with platinum based regimens is generally indicated, according to small cell carcinoma guidelines $[4,5]$.

The American Joint Committee on Cancer (AJCC) staging system for pancreatic NET is increasingly accepted as the standard staging system in North America, and is similar to the system used for pancreatic adenocarcinomas. Several other organizations, including both North-American based groups and the European Neuroendocrine Tumor Society (ENETs) have proposed similar, though not identical, staging systems for NET using the commonly accepted Tumor Node Metastasis (TNM) notation [6-10].

\section{Clinical Presentation and Initial Management}

Most pancreatic NET are considered "non-functional" in that they are not associated with symptoms of hormone hypersecretion. Such tumors are usually identified incidentally during imaging for other indications, or at an advanced stage, when patients become symptomatic from tumor bulk. Patients with hormonal hypersecretion, on the other hand, can present with diverse and sometimes puzzling clinical symptoms (Table 1). Specific recommendations for some of the more common tumors, based on the clinical presentation and hormones secreted, are described below.

\section{Insulinoma}

Insulinomas classically present with "Whipple's Triad:" a combination of symptoms of hypoglycemia, inappropriately high insulin levels with associated documented blood glucose levels of $<50 \mathrm{mg} / \mathrm{dL}$, and symptom relief with administration of glucose [11]. Initially, the hypoglycemia may be managed with dietary modifications or with diazoxide [12] For these patients, octreotide or other somatostatin analogs should be used with caution, as they have the potential to worsen hypoglycemia by suppressing glucagon secretion. Treatment with the mTOR inhibitor everolimus has also been reported to be beneficial in insulinoma patients with refractory hypoglycemia [13].

\section{Glucagonoma}

Over two-thirds of patients with glucagonomas present with necrolytic migratory erythema, a rash characterized by raised erythematous patches beginning in the perineum and progressing to the trunk and extremities $[14,15]$. Somatostatin analogs are generally successful in the initial management of patients with the glucagonoma syndrome [16,17]. Glucagonomas may be associated with diabetes mellitus, though only half of patients experience clinically significant hyperglycemia.

\section{Gastrinoma and Zollinger-Ellison syndrome}

The gastrinoma syndrome is characterized by gastric hypersecretion [18]. In patients with non-healing peptic ulcers and a fasting gastrin level $>100 \mathrm{pg} / \mathrm{mL}$, a diagnosis of gastrinoma should be considered [19]. Moderate elevations of serum gastrin may also, however, be seen in patients receiving concomitant therapy with proton pump inhibitors, sometimes complicating efforts to confirm a diagnosis. Proton pump inhibitors are a highly effective initial treatment in controlling symptoms associated with gastric hypersecretion $[20,21]$. Treatment with somatostatin analogs has also been associated with improved control of serum gastrin levels and, in some cases, with tumor stabilization or regression [22].

Table 1 Clinical presentation of pancreatic neuroendocrine tumors (NET)

\begin{tabular}{|c|c|c|c|}
\hline Tumor & Symptoms or signs & $\begin{array}{c}\begin{array}{c}\text { Incidence } \\
\text { of } \\
\text { metastases }\end{array} \\
\end{array}$ & $\begin{array}{l}\text { Extrapancreatic } \\
\text { location }\end{array}$ \\
\hline Insulinoma & $\begin{array}{l}\text { Hypoglycemia resulting in intermittent confusion, sweating, weakness, nausea; loss of } \\
\text { consciousness may occur in severe cases }\end{array}$ & $<15 \%$ & Rare \\
\hline Glucagonoma & Rash (necrotizing migratory erythema), cachexia, diabetes, deep venous thrombosis & Majority & Rare \\
\hline $\begin{array}{c}\text { VIPoma, } \\
\text { Verner-Morrison } \\
\text { Syndrome, } \\
\text { WDHA Syndrome }\end{array}$ & Profound secretory diarrhea, electrolyte disturbances & Majority & $10 \%$ \\
\hline $\begin{array}{l}\text { Gastrinoma, } \\
\text { Zollinger-Ellison } \\
\text { Syndrome }\end{array}$ & Acid hypersecretion resulting in refractory peptic ulcer disease, abdominal pain, and diarrhea & $<50 \%$ & $\begin{array}{l}\text { Frequently in } \\
\text { duodenum }\end{array}$ \\
\hline Somatostatinoma & Diabetes, diarrhea, cholelithiasis & Majority & Rare \\
\hline Non-functioning & May be first diagnosed due to mass effect & Majority & Rare \\
\hline
\end{tabular}

WDHA: Watery Diarrhea, Hypokalemia and Achlorhydria. 


\section{VIPoma}

Pancreatic endocrine tumors associated with profound diarrhea, hypokalemia, and achlorhydria were first described by Verner and Morrison in 1958 [23]. This syndrome was subsequently found to be due to ectopic vasoactive intestinal peptide (VIP) secretion. Treatment with somatostatin analogs is effective in treatment of diarrhea in these patients [24].

\section{Imaging}

Patients with functioning tumors, particularly insulinomas and gastrinomas, may develop hormonal symptoms from small primary tumors, and localization of the primary lesions may be challenging. Traditional cross-sectional imaging with triple phase CT or MRI is generally the first step in attempting to localize these tumors. Endoscopic ultrasound may be more sensitive than CT or MRI for the detection of small lesions, and may also provide useful information regarding potential vessel involvement prior to planned resection. Pancreatic NET, like carcinoid tumors, frequently over express somatostatin receptors. ${ }^{111}$ Indium-DTPA-octreotide (Octreos$\mathrm{can}^{\mathrm{TM}}$ ) has been commonly used, often in combination with cross-sectional imaging, to localize and stage pancreatic NET.

\section{Biochemical Assessment and Monitoring}

In patients with symptoms of hormone hypersecretion, serial measurements of the specific hormone may be helpful in assessing treatment response or in monitoring for recurrence. The majority of patients with pancreatic NET, however, do not have clear evidence of hormone hypersecretion. Serum chromogranin A (CGA) is a neuroendocrine secretory protein that serves as a marker of disease activity in both functional and non-functional pancreatic NET [1,25-27]. CGA may decrease in patients responding to somatostatin analogs or other therapies $[26,28]$. In patients on stable SSA doses, consistent increases in plasma CGA levels over time may reflect loss of secretory control and/or tumor growth [25-27,29,30]. Use of CGA as a diagnostic or screening test for pancreatic NET is discouraged, as CGA may be elevated in a number of non-malignant conditions, including renal insufficiency and liver disease, and in patients taking proton pump inhibitors.

\section{Surgical Management}

In general, in the absence of distant metastases or significant comorbidities, complete surgical resection of the primary tumor should be attempted [31,32]. The primary tumors in patients who are diagnosed due to symptoms of hormone hypersecretion may be occult (Figure 1A). In contrast, patients with non-functioning pancreatic NET are commonly diagnosed at a later stage

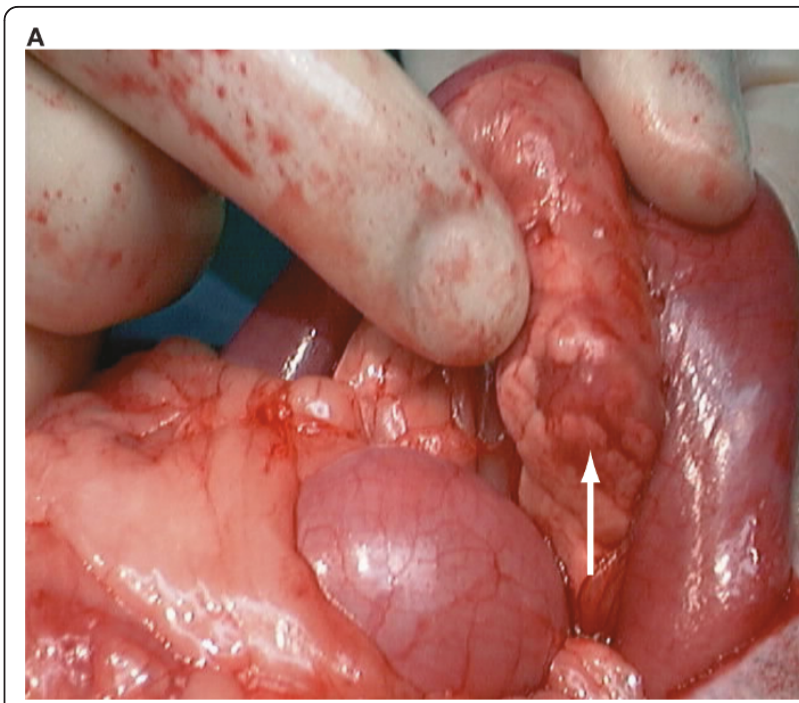

B

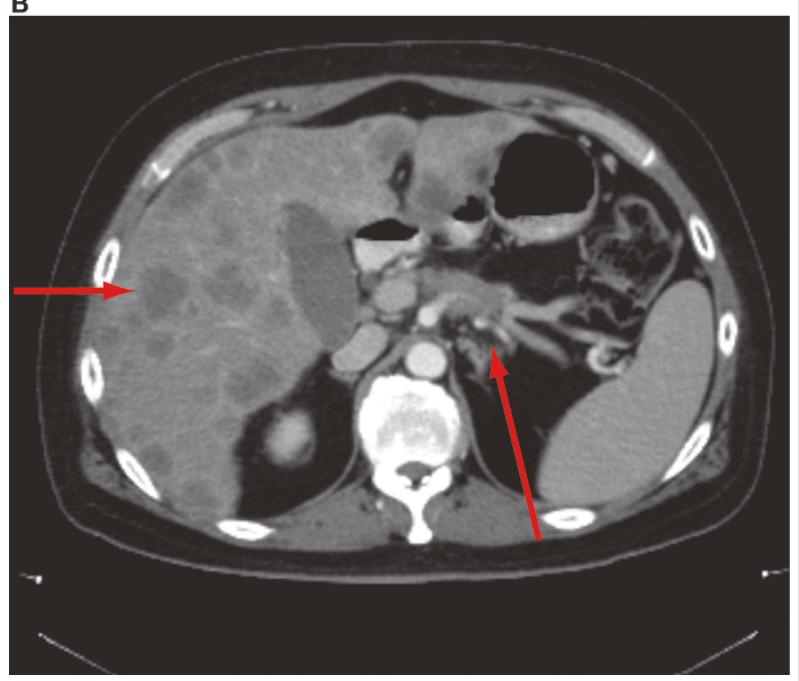

Figure 1 Variations in size of primary pancreatic NET. A: Insulinoma presenting as an occult nodule on the pancreas. Functional pancreatic NET may present at an early stage, and identification of the primary tumor may be challenging. B.

Non-functioning pancreatic NET in the tail of the pancreas with associated hepatic metastases. Non-functioning pancreatic NET more typically present at a later stage, often as bulky lesions in the tail of the pancreas with associated liver metastases.

(Figure 1B). The prognosis following surgical resection of localized NET is often excellent. Isolated insulinomas, for example, are generally treated with enucleation; long-term survival following surgery in this patient population exceeds 90\% [33]. The role of surgical resection in patients with MEN1 syndrome remains more controversial because of the risk of additional tumors within the remaining pancreas and elsewhere $[34,35]$.

In contrast to patients with pancreatic adenocarcinoma, hepatic resection may be beneficial in patients with metastatic pancreatic NET. Resection may be 
performed to render the patient free of macroscopic disease and to diminish systemic symptoms. Hepatic resection is generally favored in patients with limited hepatic disease. In a study of 170 patients, hepatic resection improved symptoms in over $90 \%$ of cases [36]. Debulking surgery in patients with more advanced disease may be recommended in selected patients if the majority (i. e., $>90 \%$ ) of the tumor burden can be resected [37]. The median survival for patients treated with this approach has been reported to be 7 years [38]. The reported survival rates for this surgical approach have been in excess of $60 \%$ at 5 years, which is twice that of patients with untreated liver metastases [38,39]. An important observation is that the survival of patients who have palliative hepatic debulking by $90 \%$ is indistinguishable from those who have complete resection (i.e., resection of all visible hepatic tumors) [39]. Also, the survival with this approach is the same among patients with functional and non-functional tumors [39]. Thus, surgical resection should be considered to potentially improve outcomes even though surgery may not be curative.

\section{Liver-directed Therapy}

In patients with hepatic metastases who are not candidates for surgical resection, hepatic arterial embolization may be an appropriate palliative technique, provided that their disease is primarily confined to the liver, the portal vein is patent, they have not undergone a Whipple procedure (or pancreaticoduodenectomy), and that patients have an otherwise preserved performance status [40-42]. Response rates are generally $>50 \%$, whether measured by reduced hormone secretion or radiographic regression [40-43]. A variety of techniques have been employed, including bland embolization, chemo-embolization, embolization with chemotherapy eluting beads, or embolization using radioisotopes. There are currently no data confirming superiority of any one of these techniques over the others.

Hepatic metastases can also be treated with percutaneous or laparoscopic radiofrequency ablation (RFA) and cryoablation, either alone or in conjunction with surgical debulking $[40,42]$. While these approaches appear to cause less morbidity than either hepatic resection or hepatic artery embolization, the clinical benefit of this approach in patients with asymptomatic, smallvolume disease has not been clearly established. Ablative techniques should be considered only in carefully selected patients $[40,42,44,45]$.

\section{Cytotoxic Chemotherapy}

Although carcinoid and pancreatic NET appear histologically similar, there is increasing evidence that pancreatic NET are more responsive to chemotherapy than are carcinoid tumors (Table 2). In an initial randomized trial, the combination of streptozocin and doxorubicin was associated with a combined biochemical and radiologic regression of $69 \%$, as well as a survival benefit when compared to streptozocin and fluorouracil [46]. The median overall survival duration for patients treated with streptozocin and doxorubicin was 2.2 years. Streptozocin was subsequently approved by the FDA as a treatment for patients with pancreatic NET. The very high response rates reported in this study were derived in part from the historical use of non-standard response criteria. A large retrospective analysis of 84 patients with either locally advanced or metastatic pancreatic endocrine tumors showed that a three-drug regimen of streptozocin, 5-FU, and doxorubicin was associated with an overall response rate of $39 \%$ and a median survival duration of 37 months [47].

Despite the demonstrated efficacy of streptozocinbased regimens, their potential toxicity, together with a cumbersome 5 consecutive day infusion schedule, has precluded their more widespread use in patients with advanced pancreatic NET. Recent prospective and retrospective studies have suggested that oral temozolomidebased regimens may be at least comparable in efficacy to streptozocin-based regimens, and may also be more tolerable. In retrospective series, temozolomide-based therapy has been associated with overall response rates of $8-70 \%$ [48-50] (Table 2). Temozolomide has been evaluated prospectively in combination with thalidomide, bevacizumab, or everolimus, with overall response rates of 24-45\% [51-53]. Neither the optimal dosing regimen for temozolomide, nor the relative activity of temozolomide as a single agent or in combination with other therapeutic agents has been clearly established.

\section{Somatostatin Analogs and Peptide Receptor Radiation Therapy (PRRT)}

More than $90 \%$ of NET express somatostatin receptors, and somatostatin analogs (SSAs) have been shown to be effective in reducing symptoms of hormone hypersecretion associated with both carcinoid and pancreatic NET. In patients with midgut carcinoid tumors, treatment with the somatostatin analog octreotide has been shown to improve time to tumor progression over placebo. Ongoing studies are currently exploring whether somatostatin analogs have a similar antiproliferative effect in patients with pancreatic NET.

The high rate of somatostatin receptor expression in pancreatic NET also provides a rationale for peptide receptor radionuclide therapy in patients with inoperable or metastatic disease. The most frequently used radionucleotides for targeted radiotherapy in NET are yttrium $\left({ }^{90} \mathrm{Y}\right)$, and lutetium $\left({ }^{177} \mathrm{Lu}\right)$, which differ from one another in terms of emitted particles, particle energy, and tissue penetration $[54,55]$. Both the yttrium 
Table 2 Selected Trials of Cytotoxic Chemotherapy in Advanced Pancreatic NET

\begin{tabular}{|c|c|c|c|c|c|}
\hline Regimen & Patients & $\begin{array}{l}\text { Tumor Response Rate } \\
(\%)\end{array}$ & $\begin{array}{l}\text { Median Progression- Free } \\
\text { Survival }\end{array}$ & $\begin{array}{l}\text { Median Overall Survival } \\
\text { (Months) }\end{array}$ & Reference \\
\hline \multicolumn{6}{|l|}{$\begin{array}{l}\text { Prospective } \\
\text { Studies }\end{array}$} \\
\hline Chlorozotocin & 33 & 30 & $17^{*}$ & 18.0 & Moertel et al. 1992 [46] \\
\hline $\begin{array}{l}\text { Fluorouracil + } \\
\text { Streptozocin }\end{array}$ & 33 & 45 & $14^{*}$ & 16.8 & Moertel et al. 1992 \\
\hline $\begin{array}{l}\text { Doxorubicin + } \\
\text { Streptozocin }\end{array}$ & 36 & 69 & $18^{*}$ & 26.4 & Moertel et al. 1992 \\
\hline$\overline{\text { DTIC }}$ & 50 & 34 & NR & 19.3 & $\begin{array}{l}\text { Ramanathan et al. } 2001 \\
\text { [67] }\end{array}$ \\
\hline $\begin{array}{l}\text { Temozolomide+ } \\
\text { Thalidomide }\end{array}$ & 11 & 45 & NR & NR & Kulke et al. 2006 [52] \\
\hline $\begin{array}{l}\text { Temozolomide+ } \\
\text { Bevacizumab }\end{array}$ & 17 & 24 & 8.6 & NR & Kulke et al. 2006 [51] \\
\hline $\begin{array}{l}\text { Temozolomide+ } \\
\text { Everolimus }\end{array}$ & 24 & 35 & NR & NR & Kulke et al. 2010 [53] \\
\hline \multicolumn{6}{|l|}{$\begin{array}{l}\text { Retrospective } \\
\text { Studies }\end{array}$} \\
\hline $\begin{array}{l}\text { Steptozocin+ } \\
\text { Doxorubicin+ } \\
\text { Fluorouracil }\end{array}$ & 84 & 39 & 18 & 37 & $\begin{array}{l}\text { Kouvaraki et al. } 2004 \\
\text { [47] }\end{array}$ \\
\hline $\begin{array}{l}\text { Temozolomide } \\
\text { (diverse regimens) }\end{array}$ & 53 & 34 & 13.6 & 35.3 & Kulke et al. 2009 [49] \\
\hline $\begin{array}{l}\begin{array}{l}\text { Temozolomide } \\
\text { (single agent) }\end{array} \\
\end{array}$ & 12 & 8 & NR & NR & Ekeblad et al. 2007 [48] \\
\hline $\begin{array}{l}\text { Temozolomide+ } \\
\text { Capecitabine }\end{array}$ & 30 & 70 & 18 & NR & $\begin{array}{l}\text { Strosberg et al. } 2010 \\
\text { [50] }\end{array}$ \\
\hline
\end{tabular}

NR: Not reported.

and the lutetium labeled compounds have demonstrated promising activity in NET patients. The radiolabeled somatostatin analog $\left[{ }^{177} \mathrm{Lu}-\mathrm{DOTA}, \mathrm{Tyr}^{3}\right]$ octreotate, for example, has been utilized in the treatment of 504 patients with NET, and efficacy results, reported for 310 patients, suggest single agent activity [56]. Treatment with ${ }^{90}$ Y-DOTA tyr3-octreotide $\left({ }^{90} \mathrm{Y}\right.$-edotreotide) was recently reported to be associated with high rates of symptom control, though only modest tumor response rates, in a prospective, phase II study [57]. Randomized studies comparing PRRT to treatment with "cold" octreotide are anticipated to better define the relative efficacy and toxicities associated with these regimens.

\section{Biologically Targeted Therapies for Pancreatic NET}

Studies of biologically targeted therapies in pancreatic NET have, to date, focused primarily on inhibitors of the VEGF or mTOR signaling pathways. While objective RECIST-defined tumor response rates have been relatively low, recent studies have suggested that treatment with these agents is associated with improvements in progression-free survival.

\section{VEGF pathway inhibitors}

Three tyrosine kinase inhibitors-pazopanib, sorafenib, and sunitinib-all with activity against VEGFR, have been evaluated in prospective trials of patients with advanced pancreatic NET. Pazopanib was evaluated in a prospective study enrolling 51 NET patients (29 with pancreatic NET and 22 with carcinoid) on stable doses of octreotide-LAR. Patients received pazopanib at a dose of $800 \mathrm{mg}$ daily. The response rate among patients with pancreatic NET was $17 \%$; no patients with carcinoid experienced a radiographic response (by RECIST) [58]. Sorafenib is another small molecule tyrosine kinase inhibitor with activity against VEGFR. In a study of 50 patients with carcinoid and 43 patients with pancreatic NET, preliminary analysis showed responses in $7 \%$ of the carcinoid patients and $11 \%$ of the pancreatic NET patients [59].

Sunitinib malate was evaluated in a multi-institutional phase II study enrolling 109 patients with advanced NET. Patients received repeated 6-week treatment cycles of sunitinib, administered orally at $50 \mathrm{mg}$ once daily for 4 weeks, followed by 2 weeks off treatment [60]. Partial responses were observed in $2 \%$ of the carcinoid cohort 
and $16 \%$ of the pancreatic NET cohort. Based on evidence of activity in this study, an international randomized phase III study to confirm the activity of sunitinib in pancreatic NET was undertaken. The study was discontinued prior to a planned interim analysis after enrollment of 171 patients, 86 of whom received sunitinib and 85 of whom received placebo. The early discontinuation of the study precluded definitive hypothesis testing for differences in progression-free survival durations between the treatment and placebo groups. Nevertheless, analysis of the available data demonstrated that treatment with sunitinib was associated with a median progression-free survival (PFS) of 11.4 months, as compared with 5.5 months for placebo $(P=.0001$, Table 3) [61].

\section{mTOR Inhibitors}

Tumor cell growth, proliferation, and apoptosis are regulated in part by a serine-threonine kinase called the mammalian target of rapamycin (mTOR). This enzyme also mediates downstream signaling from a number of pathways, including the VEGF and insulin-like growth factor (IGF) signaling implicated in NET growth. Temsirolimus and everolimus are rapamycin derivatives that have been evaluated recently in NET. Weekly intravenous administration of temsirolimus was associated with a response rate of $5.6 \%$ in one study of 37 patients with advanced progressive NET. Outcomes were similar between patients with carcinoid and pancreatic NET [62].

Everolimus was initially evaluated in a single-institution study, in which 30 patients with carcinoid tumors and 30 with pancreatic NET received doses of 5 or 10 mg daily plus depot octreotide (30 mg every 4 weeks). The overall tumor response rate in evaluable patients was $17 \%$ in carcinoid and $27 \%$ in pancreatic NET [63]. A follow-up multinational phase II study (RADIANT-1) enrolled 160 patients with advanced pancreatic NET and evidence of RECIST-defined progression following chemotherapy. In this non-randomized study, treatment with everolimus was associated with an overall response rate of $4.4 \%$ and progression-free survival duration of 16.7 months in those patients receiving octreotide. Among patients not receiving octreotide, the response rate was $9.6 \%$ and the progression-free survival duration was 9.7 months [64]. A subsequent phase III study randomized 410 patients with progressive advanced pancreatic NET (RADIANT-3) to receive treatment with everolimus or placebo; octreotide was given at the discretion of the investigator. This study demonstrated significant improvements in the primary endpoint of investigator-assess PFS associated with everolimus as compared to placebo (11 months versus 4.6 months, [P $<.0001$, Table 3]) [65]. The overall tumor response rate associated with everolimus in this study was $5 \%$.

Ongoing studies are currently evaluating combinations of targeted agents in patients with advanced pancreatic NET. A combination of the mTOR inhibitor everolimus and the VEGF inhibitor bevacizumab was recently shown to be well tolerated and associated with antitumor activity (overall response rate 26\%) in an initial phase II study enrolling patients with low or intermediate grade NET [66]. CALGB 80701 is currently randomizing patients with advanced pancreatic NET to receive either treatment with everolimus or everolimus + bevacizumab to assess the relative efficacy and toxicity of these regimens (Table 3 ).

\section{Conclusions}

Patients with pancreatic NET present with diverse symptoms related to hormonal hypersecretion, tumor bulk, or both. Accurate diagnosis of this condition and differentiation of pancreatic NET from the more common pancreatic adenocarcinomas is a critical first step in developing an appropriate treatment plan. Similarly, pancreatic NET should be considered separately from carcinoid tumors, which arise in other sites. Surgical resection remains the mainstay of treatment for patients with localized disease. A number of treatment options are available for patients with advanced pancreatic NET. These include hepaticdirected therapies, including surgical resection and hepatic artery embolization. Systemic treatment options include the use of SSAs for control of hormonal hypersecretion, as well as alkylating chemotherapy. Recent studies have also reported that the tyrosine kinase inhibitor sunitinib and the mTOR inhibitor everolimus improved progressionfree survival in patients with pancreatic NET, further

Table 3 Randomized Trials of Biologically Targeted Therapies in Pancreatic NET

\begin{tabular}{|c|c|c|c|c|c|}
\hline Regimen & $\underset{\text { (total) }}{\mathrm{N}}$ & $\begin{array}{c}\text { Overall } \\
\text { Response Rate }\end{array}$ & $\begin{array}{c}\text { Median Progression-Free } \\
\text { Survival/TTP }\end{array}$ & $\begin{array}{c}P \\
\text { value }\end{array}$ & Reference \\
\hline $\begin{array}{l}\text { Sunitinib ( } 37.5 \text { mg po qd) } \\
\text { Placebo (+ best supportive care) }\end{array}$ & 171 & $\begin{array}{l}9 \% \\
0 \% \\
\end{array}$ & $\begin{array}{l}11.4 \text { months } \\
5.5 \text { months }\end{array}$ & .0001 & $\begin{array}{l}\text { Raymond et al, } \\
2011 \text { [61] }\end{array}$ \\
\hline $\begin{array}{l}\text { Everolimus (10 mg po qd) } \\
\text { Placebo (+ best supportive care) }\end{array}$ & 410 & $\begin{array}{l}5 \% \\
2 \% \\
\end{array}$ & $\begin{array}{l}11 \text { months } \\
4.6 \text { months }\end{array}$ & $<.0001$ & $\begin{array}{c}\text { Yao et al, } 2011 \\
{[65]}\end{array}$ \\
\hline $\begin{array}{c}\text { Everolimus (10 mg po qd) } \\
\text { Everolimus (10 mg po qd) }+ \text { Bevacizumab }(10 \mathrm{mg} / \mathrm{kg} \\
\text { every other week })\end{array}$ & $\begin{array}{l}\text { CALGB } \\
80701\end{array}$ & (Ongoing) & & & \\
\hline
\end{tabular}


expanding the therapeutic arsenal available to patients with this disease. Future studies will likely build on these results, further improving therapeutic options for patients with this disease.

\section{Acknowledgements}

The authors thank Lindy Morde (Dana-Farber Cancer Institute) for providing editorial assistance. Medical writing support was also provided by Susanne Gilbert and Keith Lantz (ACUMED ${ }^{\circledR}$, New York, USA) and was funded by Pfizer Inc.

\section{Author details \\ 'Dana-Farber Cancer Institute, Boston MA, USA. ${ }^{2}$ Sarah Cannon Research Institute, Nashville, TN, USA. ${ }^{3} \mathrm{H}$ Lee Moffitt Cancer Center, Tampa FL, USA. ${ }^{4}$ Siteman Cancer Center, St Louis MO, USA. ${ }^{5}$ Oregon Health and Science University, Portland OR, USA. ${ }^{6}$ MD Anderson Cancer Center, Houston TX, USA.}

\section{Authors' contributions}

All authors were involved in drafting the manuscript and revising it critically for important intellectual content. All authors have also read and approved the final version of the manuscript to be published.

\section{Competing interests}

MK has served as a consultant for Pfizer, Novartis, Ipsen, Lexicon Pharmaceuticals, and Molecular Insight Pharmaceuticals. JB has no competing interests. LK has served as a consultant and/or received honorarium from Novartis, Pfizer, and Delcath. JP has received research funding and honorarium, and served as a consultant and as a speaker for Novartis and Pfizer. JY has served as a consultant for Ipsen, Novartis, and Pfizer.

Received: 31 March 2011 Accepted: 14 June 2011

Published: 14 June 2011

\section{References}

1. Metz DC, Jensen RT: Gastrointestinal neuroendocrine tumors: pancreatic endocrine tumors. Gastroenterology 2008, 135:1469-1492.

2. Yao JC, Hassan M, Phan A, Dagohoy C, Leary C, Mares JE, Abdalla EK, Fleming JB, Vauthey JN, Rashid A, Evans DB: One hundred years after "carcinoid": epidemiology of and prognostic factors for neuroendocrine tumors in 35,825 cases in the United States. J Clin Oncol 2008, 26:3063-3072.

3. Agarwal SK, Lee BA, Sukhodolets KE, Kennedy PA, Obungu VH, Hickman AB, Mullendore ME, Whitten I, Skarulis MC, Simonds WF, et al: Molecular pathology of the MEN1 gene. Ann N Y Acad Sci 2004, 1014:189-198.

4. Kloppel G, Perren A, Heitz PU: The gastroenteropancreatic neuroendocrine cell system and its tumors: the WHO classification. Ann NY Acad Sci 2004, 1014:13-27.

5. Rindi $G$, Kloppel $G$ : Endocrine tumors of the gut and pancreas tumor biology and classification. Neuroendocrinology 2004, 80(Suppl 1):12-15.

6. Klimstra DS, Modlin IR, Adsay NV, Chetty R, Deshpande V, Gonen M, Jensen RT, Kidd M, Kulke MH, Lloyd RV, Moran C, Moss SF, Oberg K OToole D, Rindi G, Robert ME, Suster S, Tang LH, Tzen CY, Washington MK, Wiedenmann B, Yao J: Pathology reporting of neuroendocrine tumors: application of the Delphic consensus process to the development of a minimum pathology data set. Am J Surg Pathol 2010, 34:300-313.

7. Klimstra DS, Modlin IR, Coppola D, Lloyd RV, Suster S: The pathologic classification of neuroendocrine tumors: a review of nomenclature, grading, and staging systems. Pancreas 2010, 39:707-712.

8. Rindi G, Kloppel G, Alhman H, Caplin M, Couvelard A, de Herder WW, Erikssson B, Falchetti A, Falconi M, Komminoth P, Korner M, Lopes JM, McNicol AM, Nilsson O, Perren A, Scarpa A, Scoazec JY, Wiedenmann B, All of the Frascati concencus conference participants European Neuroendocrine Tumour Society (ENTS): TNM staging of foregut (neuro) endocrine tumors: a consensus proposal including a grading system. Virchows Arch 2006, 449:395-401.

9. Rindi G, Kloppel G, Couvelard A, Komminoth P, Korner M, Lopes JM, McNicol AM, Nilsson O, Perren A, Scarpa A, Scoazec JY, Wiedenmann B:
TNM staging of midgut and hindgut (neuro) endocrine tumors: a consensus proposal including a grading system. Virchows Arch 2007, 451:757-762.

10. Edge SB, Compton CC: The American Joint Committee on Cancer: the 7th edition of the AJCC cancer staging manual and the future of TNM. Ann Surg Oncol 2010, 17:1471-1474.

11. Whipple AO, Frantz VK: Adenoma of islet cells with hyperinsulinism: a review. Ann Surg 1935, 101:1299-1335.

12. Goode PN, Farndon JR, Anderson J, Johnston ID, Morte JA: Diazoxide in the management of patients with insulinoma. World J Surg 1986, 10:586-592.

13. Kulke MH, Bergsland EK, Yao JC: Glycemic control in patients with insulinoma treated with everolimus. N Engl I Med 2009, 360:195-197.

14. Horrobin DF, Cunnane SC: Interactions between zinc, essential fatty acids and prostaglandins: relevance to acrodermatitis enteropathica, total parenteral nutrition, the glucagonoma syndrome, diabetes, anorexia nervosa and sickle cell anaemia. Med Hypotheses 1980, 6:277-296.

15. Roth E, Muhlbacher F, Karner J, Hamilton G, Funovics J: Free amino acid levels in muscle and liver of a patient with glucagonoma syndrome. Metabolism 1987, 36:7-13.

16. El RZ, Partensky C, Valette PJ, Berger F, Chayvialle JA: Necrolytic migratory erythema, first symptom of a malignant glucagonoma: treatment by long-acting somatostatin and surgical resection. Report of three cases. Eur J Surg Oncol 1998, 24:562-567.

17. Jockenhovel F, Lederbogen S, Olbricht T, Schmidt-Gayk H, Krenning EP, Lamberts SW, Reinwein D: The long-acting somatostatin analogue octreotide alleviates symptoms by reducing posttranslational conversion of prepro-glucagon to glucagon in a patient with malignant glucagonoma, but does not prevent tumor growth. Clin Investig 1994 72:127-133.

18. Zollinger RM, Ellison EH: Primary peptic ulcerations of the jejunum associated with islet cell tumors of the pancreas. Ann Surg 1955, 142:709-723.

19. Jensen RT: Gastrointestinal endocrine tumours. Gastrinoma. Baillieres Clin Gastroenterol 1996, 10:603-643.

20. Lambers CB, Lind T, Moberg S, Jansen JB, Olbe L: Omeprazole in ZollingerEllison syndrome. Effects of a single dose and of long-term treatment in patients resistant to histamine H2-receptor antagonists. N Engl I Med 1984, 310:758-761

21. Frucht $H$, Maton PN, Jensen RT: Use of omeprazole in patients with Zollinger-Ellison syndrome. Dig Dis Sci 1991, 36:394-404.

22. Shojamanesh H, Gibril F, Louie A, Ojeaburu JV, Bashir S, bou-Saif A, Jensen RT: Prospective study of the antitumor efficacy of long-term octreotide treatment in patients with progressive metastatic gastrinoma. Cancer 2002, 94:331-343.

23. Verner $J \mathrm{~V}$, Morrison $\mathrm{AB}$ : Islet cell tumor and a syndrome of refractory watery diarrhea and hypokalemia. Am J Med 1958, 25:374-380.

24. Kraenzlin ME, Ch'ng JL, Wood SM, Carr DH, Bloom SR: Long-term treatment of a VIPoma with somatostatin analogue resulting in remission of symptoms and possible shrinkage of metastases. Gastroenterology 1985, 88:185-187.

25. de Herder WW: Biochemistry of neuroendocrine tumours. Best Pract Res Clin Endocrinol Metab 2007, 21:33-41.

26. Oberg K, Eriksson B: Endocrine tumours of the pancreas. Best Pract Res Clin Gastroenterol 2005, 19:753-781.

27. Ardill JE: Circulating markers for endocrine tumours of the gastroenteropancreatic tract. Ann Clin Biochem 2008, 45:539-559.

28. Oberg K, Kvols L, Caplin M, Delle FG, de HW, Rindi G, Ruszniewski P, Woltering EA, Wiedenmann B: Consensus report on the use of somatostatin analogs for the management of neuroendocrine tumors of the gastroenteropancreatic system. Ann Oncol 2004, 15:966-973.

29. Kann PH, Balakina E, Ivan D, Bartsch DK, Meyer $S$, Klose KJ, Behr T, Langer P: Natural course of small, asymptomatic neuroendocrine pancreatic tumours in multiple endocrine neoplasia type 1: an endoscopic ultrasound imaging study. Endocr Relat Cancer 2006, 13:1195-1202

30. Janson ET, Holmberg L, Stridsberg M, Eriksson B, Theodorsson E, Wilander E, Oberg K: Carcinoid tumors: analysis of prognostic factors and survival in 301 patients from a referral center. Ann Oncol 1997, 8:685-690.

31. Norton JA, Fraker DL, Alexander HR, Gibril F, Liewehr DJ, Venzon DJ, Jensen RT: Surgery increases survival in patients with gastrinoma. Ann Surg 2006, 244:410-419. 
32. Fraker DL, Norton JA, Alexander HR, Venzon DJ, Jensen RT: Surgery in Zollinger-Ellison syndrome alters the natural history of gastrinoma. Ann Surg 1994, 220:320-328.

33. Service FJ, McMahon MM, O'Brien PC, Ballard DJ: Functioning insulinomaincidence, recurrence, and long-term survival of patients: a 60-year study. Mayo Clin Proc 1991, 66:711-719.

34. O'Riordain DS, O'Brien T, van Heerden JA, Service FJ, Grant CS: Surgical management of insulinoma associated with multiple endocrine neoplasia type I. World J Surg 1994, 18:488-493.

35. Demeure MJ, Klonoff DC, Karam JH, Duh QY, Clark OH: Insulinomas associated with multiple endocrine neoplasia type I: the need for a different surgical approach. Surgery 1991, 110:998-1004

36. Sarmiento JM, Que FG: Hepatic surgery for metastases from neuroendocrine tumors. Surg Oncol Clin N Am 2003, 12:231-242.

37. Que FG, Nagorney DM, Batts KP, Linz LJ, Kvols LK: Hepatic resection for metastatic neuroendocrine carcinomas. Am J Surg 1995, 169:36-42.

38. Sarmiento JM, Heywood G, Rubin J, Ilstrup DM, Nagorney DM, Que FG: Surgical treatment of neuroendocrine metastases to the liver: a plea for resection to increase survival. J Am Coll Surg 2003, 197:29-37.

39. Dousset B, Saint-Marc O, Pitre J, Soubrane O, Houssin D, Chapuis Y: Metastatic endocrine tumors: medical treatment, surgical resection, or liver transplantation. World J Surg 1996, 20:908-914.

40. Steinmuller T, Kianmanesh R, Falconi M, Scarpa A, Taal B, Kwekkeboom DJ, Lopes JM, Perren A, Nikou G, Delle Fave GF, OToole D, Frascati Concensus Conference Participants: Consensus guidelines for the management of patients with liver metastases from digestive (neuro)endocrine tumors: foregut, midgut, hindgut, and unknown primary. Neuroendocrinology 2008, 87:47-62.

41. Toumpanakis C, Meyer T, Caplin ME: Cytotoxic treatment including embolization/chemoembolization for neuroendocrine tumours. Best Pract Res Clin Endocrinol Metab 2007, 21:131-144.

42. O'Toole D, Ruszniewski P: Chemoembolization and other ablative therapies for liver metastases of gastrointestinal endocrine tumours. Best Pract Res Clin Gastroenterol 2005, 19:585-594.

43. Gupta S, Yao JC, Ahrar K, Wallace MJ, Morello FA, Madoff DC, Murthy R, Hicks ME, Ajani JA: Hepatic artery embolization and chemoembolization for treatment of patients with metastatic carcinoid tumors: the M.D. Anderson experience. Cancer J 2003, 9:261-267.

44. Mazzaglia PJ, Berber E, Milas M, Siperstein AE: Laparoscopic radiofrequency ablation of neuroendocrine liver metastases: a 10-year experience evaluating predictors of survival. Surgery 2007, 142:10-19.

45. Elvin A, Skogseid B, Hellman P: Radiofrequency ablation of neuroendocrine liver metastases. Abdom Imaging 2005, 30:427-434.

46. Moertel CG, Lefkopoulo M, Lipsitz S, Hahn RG, Klaassen D: Streptozocindoxorubicin, streptozocin-fluorouracil or chlorozotocin in the treatment of advanced islet-cell carcinoma. N Engl J Med 1992, 326:519-523.

47. Kouvaraki MA, Ajani JA, Hoff P, Wolff R, Evans DB, Lozano R, Yao JC: Fluorouracil, doxorubicin, and streptozocin in the treatment of patients with locally advanced and metastatic pancreatic endocrine carcinomas. $J$ Clin Oncol 2004, 22:4762-4771.

48. Ekeblad S, Sundin A, Janson ET, Welin S, Granberg D, Kindmark H, Dunder K, Kozlovacki G, Orlefors H, Sigurd M, Obergo K, Erriksson B, Skogseid B: Temozolomide as monotherapy is effective in treatment of advanced malignant neuroendocrine tumors. Clin Cancer Res 2007, 13:2986-2991.

49. Kulke MH, Hornick JL, Frauenhoffer C, Hooshmand S, Ryan DP, Enzinger PC, Meyerhardt JA, Clark JW, Stuart K, Fuchs CS, Redston MS: 06methylguanine DNA methyltransferase deficiency and response to temozolomide-based therapy in patients with neuroendocrine tumors. Clin Cancer Res 2009, 15:338-345.

50. Strosberg JR, Fine RL, Choi J, Nasir A, Coppola D, Chen DT, Helm J, Kvols L: First-line chemotherapy with capecitabine and temozolomide in patients with metastatic pancreatic endocrine carcinomas. Cancer 2011, 117:268-275

51. Kulke MH, Stuart K, Earle C: A phase II study of temozolomide and bevacizumab in patients with advance neuroendocrine tumors [abstract]. ASCO Annual Meeting Proc 2006, 24:4044a.

52. Kulke MH, Stuart K, Enzinger PC, Ryan DP, Clark JW, Muzikansky A, Vincitore M, Michelini A, Fuchs CS: Phase II study of temozolomide and thalidomide in patients with metastatic neuroendocrine tumors. J Clin Oncol 2006, 24:401-406.
53. Kulke MH, Blaszkowsky L, Zhu A: Phase I/II study of everolimus (RAD001) in combination with temozolomide in patients with advanced pancreatic neuroendocrine tumors [abstract]. Gastrointestinal Cancers Symposium 2010, 223a.

54. Breeman WA, de JM, Kwekkeboom DJ, Valkema R, Bakker WH, Kooij PP, Visser TJ, Krenning EP: Somatostatin receptor-mediated imaging and therapy: basic science, current knowledge, limitations and future perspectives. Eur J Nucl Med 2001, 28:1421-1429.

55. Teunissen JJ, Kwekkeboom DJ, de JM, Esser JP, Valkema R, Krenning EP, Endocrine tumours of the gastrointestinal tract: Peptide receptor radionuclide therapy. Best Pract Res Clin Gastroenterol 2005, 19:595-616.

56. Kwekkeboom DJ, de Herder WW, Kam BL, van Eijck CH, van EM, Kooij PP, Feelders RA, van Aken MO, Krenning EP: Treatment with the radiolabeled somatostatin analog [177 Lu-DOTA 0,Tyr3]octreotate: toxicity, efficacy, and survival. J Clin Oncol 2008, 26:2124-2130.

57. Bushnell DL, O'Dorisio TM, O'Dorisio MS, Menda Y, Hicks RJ, Van CE, Baulieu JL, Borson-Chazot F, Anthony L, Benson AB, Oberg K, Grossman AB, Connolly M, Bouterfa H, Li Y, Kacena KA, LaFrance N, Pauwels SA: 90Yedotreotide for metastatic carcinoid refractory to octreotide. J Clin Oncol 2010, 28:1652-1659.

58. Phan A, Yao J, Fogelman D: A prospective, multi-institutional phase II study of GW786034 (pazopanib) and depot octreotide in advanced lowgrade neuroendocrine carcinoma [abstract]. J Clin Oncol 2010, 28.

59. Hobday TJ, Rubin J, Holen K, Picus J, Donehower R, Marschke R, Maples W, Lloyd R, Mahoney M, Erlichman C: MC044h, a phase II trial of sorafenib in patients with metastatic neuroendocine tumors: a phase II consortium study [abstract]. ASCO Annual Meeting Proc 2007, 25:4505a.

60. Kulke MH, Lenz HJ, Meropol NJ, Posey J, Ryan DP, Picus J, Bergsland E, Stuart K, Tye L, Huang X, Li ZJ, Baum CM, Fuchs CS: Activity of sunitinib in patients with advanced neuroendocrine tumors. J Clin Oncol 2008, 26:3403-3410.

61. Raymond E, Dahan L, Raoul JL, Bang YJ, Borbath I, Lombard-Bohas C, Valle J, Metrakos P, Smith D, Vinik A, Chen JS, Horsch D, Hammel P, Wiedenmann B, Van Cutsem E, Patyna S, Lu DR, Blanckmeister C, Chao R, Ruszniewski P: Sunitinib malate for the treatment of pancreatic neuroendocrine tumors. N Engl J Med 2011, 364:501-513.

62. Duran I, Kortmansky J, Singh D, Hirte H, Kocha W, Goss G, Le L, Oza A, Nicklee T, Ho J, Birle D, Pond GR, Arboine D, Dancey J, Aviel-Ronan S, Tsao MS, Hedley D, Siu LL: A phase II clinical and pharmacodynamic study of temsirolimus in advanced neuroendocrine carcinomas. $\mathrm{Br} J$ Cancer 2006, 95:1148-1154.

63. Yao JC, Phan AT, Chang DZ, Wolff RA, Hess K, Gupta S, Jacobs C, Mares JE, Landgraf AN, Merci-Bernstam F: Efficacy of RAD001 (everolimus) and octreotide LAR in advanced low- to intermediate-grade neuroendocrine tumors: results of a phase II study. J Clin Oncol 2008, 26:4311-4318.

64. Yao JC, Lombard-Bohas C, Baudin E, Kvols LK, Rougier P, Ruszniewski P, Hoosen S, St PJ, Haas T, Lebwohl D, Van Cutsem E, Kulke MH, Hobday TJ, O'Dorisio TM, Shah MH, Cadiot G, Luppi G, Posey JA, Wiedenmann B: Daily oral everolimus activity in patients with metastatic pancreatic neuroendocrine tumors after failure of cytotoxic chemotherapy: a phase II trial. J Clin Oncol 2010, 28:69-76.

65. Yao JC, Shah MH, Ito T, Bohas CL, Wolin EM, Van CE, Hobday TJ, Okusaka T, Capdevila J, de Vries EG, Tomassetti P, Pavel ME, Hoosen S, Haas T, Lincy J, Lebwohl D, Oberg K, RAD001 in Advanced Neuroendocrine Tumors Third Trial (RADIANT-3) Study Group: Everolimus for advanced pancreatic neuroendocrine tumors. N Engl J Med 2011, 364:514-523.

66. Yao J, Phan A, Fogelman D: Randominzed run-in study of bevacizumab and everolimus in low to intermediate grade neuroendocrine tumors using perfusion CT as a functional biomarker [abstract]. J Clin Oncol 2011, 28.

67. Ramanathan RK, Cnaan A, Hahn RG, Carbone PP, Haller DG: Phase II trial of dacarbazine (DTIC) in advanced pancreatic islet cell carcinoma. Study of the Eastern Cooperative Oncology Group-E6282. Ann Oncol 2001, 12:1139-1143.

doi:10.1186/1756-8722-4-29

Cite this article as: Kulke et al:: Evolving Diagnostic and Treatment Strategies for Pancreatic Neuroendocrine Tumors. Journal of Hematology \& Oncology 2011 4:29. 